\title{
Growth and yield response of lettuce and tomato grown under drip and manual irrigation
}

\author{
Nelda R. Gonzaga", Sarah Lyn A. Pepito', Renan P. Octavio', Apolinario B. \\ Gonzaga Jr' and Gordon Rogers ${ }^{2}$
}

\begin{abstract}
Although there are new and innovative irrigation techniques available locally in Mindanao (Southern Philippines), growers still rely on the traditional method manual irrigation. The study was conducted to determine the effects of irrigation method on the performance of lettuce and tomato. The study was laid out in factorial arrangement in Randomized Complete Block Design (RCBD) with different irrigation method (manual \& drip) as treatments replicated three times. In tomato, drip irrigation produced larger fruits (polar \& equatorial measurement), highest number of marketable fruits, and highest yield per hectare. While in lettuce, it resulted in larger crown size (polar measurement), highest marketable yield per plant and per hectare. The study suggests that drip irrigation could improve the present farming situation in Mindanao, considering its potential to sustain farming during times of climatic uncertainty. Thus, further trials are required to verify its effects before introduction throughout the region.
\end{abstract}

Keywords: AVTO 1173 genotype, drip irrigation, improve yield, manual irrigation, Romaine variety

\section{INTRODUCTION}

Water availability is generally the most important natural factor limiting the widespread development of agriculture. This has led to innovations for saving irrigation water and increasing crop water use efficiency (Gencoglan et al 2006, Bozkurt \& Bozkurt 2011). To minimize the negative effects of drought on plant growth, irrigation is required but it should be applied with care not only to avoid environmental problem such as runoff and groundwater contamination, but also preserve water supplies and minimize irrigation costs (DeTar et al 2006, Kizil et al 2012). Well managed subsurface drip irrigation systems save irrigation water in

' College of Agriculture University of Science and Technology of Southern Philippines - Claveria MOSCAT Compound, Poblacion, Claveria 9004, Misamis Oriental, Philippines

${ }^{2}$ Applied Horticultural Research, Eveleigh, NSW Australia

* Corresponding Author. Address: University of Science and Technology of Southern Philippines Claveria, MOSCAT Compound, Poblacion, Claveria 9004, Misamis Oriental, Philippines; Email: npr.gonzaga@gmail.com

DOI: $10.32945 /$ atr39sb14.2017 
Growth and yield response of lettuce and tomato

many agricultural crops because water is applied directly to the root zone, reducing losses to evaporation or runoff. (Suarez-Rey et al 2006, Bozkurt \& Bozkurt 2011).

Water loss can result in nutrient loss through percolation. However, drip irrigation reduces deep percolation, evaporation, controls soil water status more precisely within the crop root zone and improves fertilizer use efficiency (Singandhupe et al 2003).

According to Sanders et al 1989, Tan 1995, Thompson \& Doerge 1996a-1996b) drip irrigation has many advantages over other types of irrigation and it is the most effective way to supply water and nutrients to the plant, which not only saves water but also increases yield of fruit and vegetable crops (Tiwari et al $1998 \mathrm{a}, \mathrm{b}$ ).

Drip irrigation increased tomato yield and water use efficiency by 19 and $20 \%$, respectively, over surface irrigation (Pruitt et al 1989, Singandhupe et al 2003). Under adequate water supply, the stomatal resistance decreases and under inadequate supply it increases which leads to moisture stress in plants (Katerji et al 1987, Singandhupe et al 2003) which is one of the greatest factor to reduce plant growth. Sufficient and balanced irrigation proved to maximise yield per unit area (Pruitt et al 1989, Singandhupe et al 2003).

In Claveria, Misamis Oriental - manual irrigation is the most common irrigation method used. Although there are new and more innovative irrigation techniques and equipment, local growers still rely on this traditional, labour-intensive method of irrigation. Also, they farmers often think installation of drip and other irrigation systems is costly, discouraging them from adopting these systems. Therefore, the study was conducted to compare the effects of manual and drip irrigation on yield of lettuce and tomato.

\section{MATERIALS AND METHODS}

\section{Experimental Site}

The experiment was conducted at the Agriculture Experiment Station of University of Science and Technology of Philippines - Claveria Campus, Claveria, Misamis Oriental. Two trials were conducted on both lettuce and tomato. Lettuce was produced from September to October 2016 (first cropping) and February to April 2017 (second cropping). In tomato, the first cropping was from February to May 2016 followed by a second cropping on June to October 2016.

\section{Experimental Design and Treatments}

The study was laid-out in Randomized Complete Block Design (RCBD) with the different irrigation method, namely manual and drip irrigation as treatments replicated three times.

\section{Cultural Management Practices}

The land was cultivated and harrowed twice thoroughly using draft animal. For the lettuce, raised beds measuring $1 \mathrm{~m} \times 6 \mathrm{~m}$ with 4 rows per plot and 8 plants per row. In tomato, plots were established with a dimension of $1 \mathrm{~m} \times 5 \mathrm{~m}$ with two rows per plot and 10 plants per row. A distance of $1 \mathrm{~m}$ was left between plots and $0.5 \mathrm{~m}$ between 
Gonzaga et al

treatments for both commodities.

Installation of drip irrigation system followed immediately after transplanting. Drip lines were aligned parallel in every row. The irrigation was usually done two hours every day from 7:00am to 9:00am, although when rain occurred, irrigation was turned off. Manual irrigation was done through a sprinkler sprinkled water on plants until plots were fully and sufficiently wet.

The seedlings raised in trays were transplanted at about four to five weeks after sowing at a planting distance of $0.5 \mathrm{~m} \times 0.5 \mathrm{~m}$ (tomato) arranged in double row using AVTO 1173 , a tomato line, while lettuce was planted at a distance of $0.3 \mathrm{mx} 0.3 \mathrm{~m}$ using Romaine (leafy-type).

Fertilization of tomato was by basal application, with commercial organic fertilizer at a rate of $20 \mathrm{~g}$ plus $10 \mathrm{~g}$ of complete fertilizer (14-14-14). Side dressings were applied with $10 \mathrm{~g}$ of complete fertilizer (14-14-14), at 15 days after transplanting (DAT) while $10 \mathrm{~g}$ urea (46-0-0) and $10 \mathrm{~g}$ of muriate of potash (0-0-60) per hill was applied at 21 DAT. Fertigation was done at 40 DAT and was applied weekly right after the weekly harvest, with the mixture of $8 \mathrm{~kg}$ urea (46-0-0), $8 \mathrm{~kg}$ muriate of potash (0-0-60), and $16 \mathrm{~kg}$ of a commercial organic fertilizer, Well Grow (1.1-2.83-1.61 of N-P2O5-K2O with $5.78 \% \mathrm{Ca}$ and some amount of trace elements eg, $0.87 \% \mathrm{Fe}, 0.019 \% \mathrm{Cu}, 8.312 \mathrm{ppm} \mathrm{Mg}$, 927ppm Mn, \& 339ppm Zn) diluted in 200L of water. Basal application in lettuce was done using $10 \mathrm{~g}$ of vermicast at transplanting. Side dress applications of $0.27 \mathrm{~g}$ urea $(46-0-0), 1.85 \mathrm{~g}$ Solophos (0-180 ) and $0.89 \mathrm{~g}$ potash (0-0-60) were applied to each plant at 7, 14, and 21 DAT and did not receive any fertigation. Spraying of insecticides (Lannate ${ }^{\mathrm{TM}} \&$ Karate ${ }^{\circledast}$ ) and fungicides (Daconi ${ }^{\mathrm{TM}}$ ) were done weekly on tomato. The rate of application would change as necessary. The lettuce was kept free from any insectides and fungicides and sprayed chemicals all throughout the study.

First harvesting of tomato was at 61 DAT with up to four further harvests. Lettuce was harvested when the head was full and compact at about 30 days after transplanting. After harvesting, tomatoes and lettuce were classified as marketable or non-marketable.

\section{Data Collection and Analysis}

Parameters such as fruit and crown size (polar \& equatorial length), yield per plant (marketable \& non-marketable), yield per hectare were measured on both commodities while number of fruits (marketable \& non-marketable) and weight per fruit were collected solely on tomato. The yield per hectare for both crops were computed by basis on the marketable yield per plant only.

Data obtained were subjected to analysis of variance (ANOVA) using ASSISTAT (version 7.0 beta). The Tukey test was used to determine the significant differences among treatments means at $(p<0.05)$ level of significance.

\section{RESULTS AND DISCUSSIONS}

\section{Tomato Fruit Size}

Plots subjected to drip irrigation resulted in larger polar and fruit width compared with those plants manually irrigated during the first cropping (Table 1). This confirms the observation of Yohannes \& Tadesse (1998) that fruit size of 
Growth and yield response of lettuce and tomato

tomato was increased by drip systems. However, during the second cropping, fruit were a similar size regardless of the irrigation method.

\section{Lettuce Crown Size}

Lettuce grown with drip irrigation had higher polar size of lettuce heads compared with the manual irrigation during the first cropping (Table 1) affirmed the finding of Tiwari et al (1998) that drip irrigation is the most effective way to supply water and nutrients to the plant which not only save water but also increases yield. On the other hand, equatorial size did not differ between the irrigation methods in both cropping seasons.

Table 1. Effect of different irrigation method on the fruit and crown size of tomato and lettuce during the two-cropping period

\begin{tabular}{lcccccccc}
\hline & \multicolumn{4}{c}{ Fruit Size $(\mathrm{cm})$} & \multicolumn{4}{c}{ Crown Size $(\mathrm{cm})$} \\
\cline { 2 - 9 } Treatments & \multicolumn{3}{c}{ Tomato } & \multicolumn{4}{c}{ Lettuce } \\
\cline { 2 - 9 } & \multicolumn{3}{c}{ Polar } & \multicolumn{2}{c}{ Equatorial } & \multicolumn{2}{c}{ Polar } & \multicolumn{2}{c}{ Equatorial } \\
\cline { 2 - 9 } & FC & SC & FC & SC & FC & SC & FC & SC \\
\hline Irrigation Method & & & & & & & & \\
$\quad$ Manual & $3.58 \mathrm{~b}$ & 4.78 & $2.81 \mathrm{~b}$ & 3.51 & 26.88 & $11.37 \mathrm{~b}$ & 21.93 & 11.25 \\
$\quad$ Drip & $5.06 \mathrm{a}$ & 5.32 & $3.89 \mathrm{a}$ & 4.01 & 29.10 & $17.23 \mathrm{a}$ & 24.03 & 14.93 \\
\hline
\end{tabular}

FC - First Cropping, SC - Second Cropping

Means in a column having the same letter are not significantly different at $5 \%$ level.

\section{Yield}

Drip irrigation increased the marketable yield of lettuce by $21 \%$ compared with those plants grown under manual irrigation, in both cropping seasons. This could be attributed to its enlarged polar size (Table 2). Drip irrigation proved to have many advantages over other types of irrigation (Sanders et al 1989, Tan 1995, Thompson \& Doerge 1996a-1996b) wherein facilitates higher and better-quality yields through uniform soil moisture distribution in the root zone continuously, introduce and increases the effectiveness of fertilizers (Acar et al 2008) and water at high uniformity (Pereira 1999 cited by Pereira et al 2002, Hansona et al 1997), which possibly lead to improved lettuce yield. Moreover, subsurface drip maximized yields and reduced water demand relatively (Ayars et al 1999, Pereira et al 2002).

Table 2. Yield performance of tomato and lettuce subjected to different irrigation method

\begin{tabular}{|c|c|c|c|c|c|c|c|c|}
\hline \multirow{4}{*}{ Treatments } & \multicolumn{8}{|c|}{ Yield Per Plant (kg) } \\
\hline & \multicolumn{4}{|c|}{ Tomato } & \multicolumn{4}{|c|}{ Lettuce } \\
\hline & \multicolumn{2}{|c|}{ Marketable } & \multicolumn{2}{|c|}{$\begin{array}{c}\text { Non- } \\
\text { Marketable }\end{array}$} & \multicolumn{2}{|c|}{ Marketable } & \multicolumn{2}{|c|}{ Non-Marketable } \\
\hline & $\mathrm{FC}$ & SC & $\mathrm{FC}$ & $\mathrm{SC}$ & $\mathrm{FC}$ & SC & $\mathrm{FC}$ & SC \\
\hline \multicolumn{9}{|l|}{ Irrigation Method } \\
\hline Manual & $0.27 \mathrm{~b}$ & 0.62 & $0.23 a$ & 0.29 & $176.95 b$ & $102.87 \mathrm{~b}$ & $84.20 \mathrm{~b}$ & $32.77 \mathrm{~b}$ \\
\hline Drip & $1.06 \mathrm{a}$ & 1.04 & $0.08 \mathrm{~b}$ & 0.32 & $224.61 \mathrm{a}$ & $120.47 a$ & $102.18 \mathrm{a}$ & $46.77 a$ \\
\hline
\end{tabular}

FC - First Cropping, SC - Second Cropping

Means in a column having the same letter are not significantly different at $5 \%$ level. 
Another contributing factor in the increase of yield in lettuce under drip irrigation is lesser stress among plants. Water stress is known to reduce leaf area that causes leaf curling, wilting, and rapid senescence (Kim et al 2011 as mentioned by Kizil et al 2012) which makes more unfavourable for manual irrigation to attain higher yield compare with the drip irrigation. Kizil et al 2012 stated that as the water stress decreases, lettuce yield increases accordingly. Reported results of water stress on lettuce yield characteristics varied probably depending on the severity and duration (Soundy et al 2005 cited by Kizil et al 2012).

Use of drip lines increased the yield of tomato, as well number of marketable fruits and weight per fruit consequently got the highest yield per hectare (Tables 2 and 3). The notable increase in yield could be associated with having a higher number of fruit and larger size. Li et al 2015 found the same conclusions on both tomato and corn, that aside from saving water, drip irrigation increases crop production.

Table 3. Number of fruits and weight per fruit of tomato in response to varying irrigation method

\begin{tabular}{|c|c|c|c|c|c|c|}
\hline \multirow{3}{*}{ Treatments } & \multicolumn{4}{|c|}{ Number of Fruits } & \multicolumn{2}{|c|}{$\begin{array}{l}\text { Weight Per Fruit } \\
\text { (grams) }\end{array}$} \\
\hline & \multicolumn{2}{|c|}{ Marketable } & \multicolumn{2}{|c|}{ Non- Marketable } & \multirow[b]{2}{*}{ FC } & \multirow[b]{2}{*}{ SC } \\
\hline & FC & SC & FC & SC & & \\
\hline \multicolumn{7}{|l|}{ Irrigation Method } \\
\hline Manual & $33.47 \mathrm{~b}$ & 52.47 & $13.40 \mathrm{a}$ & 13.40 & $19.67 \mathrm{~b}$ & $28.64 b$ \\
\hline Drip & $91.27 \mathrm{a}$ & 69.80 & $4.47 \mathrm{~b}$ & 10.87 & $43.50 \mathrm{a}$ & $45.72 a$ \\
\hline
\end{tabular}

FC - First Cropping, SC - Second Cropping

Means in a column having the same letter are not significantly different at $5 \%$ level.

Table 4. Effect of different irrigation method on the yield per hectare of tomato and lettuce during the two-cropping period

\begin{tabular}{lrrrc}
\hline \multirow{2}{*}{ Treatments } & \multicolumn{5}{c}{ Yield $\left(\mathrm{t} \mathrm{ha}^{-1}\right)$} \\
\cline { 2 - 5 } & \multicolumn{3}{c}{ Tomato } & Lettuce \\
\cline { 2 - 5 } & $\mathrm{FC}$ & $\mathrm{SC}$ & $\mathrm{FC}$ & $\mathrm{SC}$ \\
\hline Irrigation Method & & & & \\
Manual & $9.78 \mathrm{~b}$ & 22.63 & $17.70 \mathrm{~b}$ & $10.29 \mathrm{~b}$ \\
Drip & $38.23 \mathrm{a}$ & 37.57 & $22.46 \mathrm{a}$ & $12.05 \mathrm{a}$ \\
\hline
\end{tabular}

FC - First Cropping, SC - Second Cropping

Means in a column having the same letter are not significantly different at $5 \%$ level.

\section{CONCLUSIONS}

The study revealed the significant effect of drip irrigation in enhancing the yield characteristics of both lettuce and tomato. Tomatoes grown under drip irrigation produced larger fruits (polar \& equatorial measurement), higher number of marketable fruits and heavier fruit, with a higher yield per hectare at first cropping. Lettuce subjected to drip irrigation produced larger crown size (polar), higher marketable yield per plant and per hectare in both cropping period impying that drip irrigation works better in fast growing crops like lettuce.

The results suggest that effects of drip irrigation on yield and quality could improve the farming situation of the local farmers who still rely on manual irrigation. 
Growth and yield response of lettuce and tomato

Therefore, further trials on identification of water and time saving benefits should be done considering its potential benefit to sustain farming activities enough to outweigh drip irrigation cost.

\section{REFERENCES}

Acar B, Paksoy M, Türkmen Ö \& Seymen M. 2008. Irrigation and nitrogen level affect lettuce yield in greenhouse condition. African Journal of Biotechnology 7(24):4450-4453

Ayars JE, Phene CJ, Hutmacher RB, Davis KR, Schoneman RA, Vail SS \& Mead RM. 1999. Subsurface drip irrigation of row crops: a review of 15 years of research at the Water Management Research Laboratory. Agricultural water management 42(1):1-27

Hansona BR, SchwankI LJ, Schulbach KF \& Pettygrove GS. 1997. A comparison of furrow, surface drip, and subsurface drip irrigation on lettuce yield and applied water. Agricultural Water Management 33(2-3):139-157

Kizil Ü, Genc L, Inalpulat M, Şapolyo D \& Mirik M. 2012. Lettuce (Lactuca sativa L.) yield prediction under water stress using artificial neural network (ANN) model and vegetation indices. Žemdirbysté= Agriculture 99(4):409-418

Li X, Shi H, Šimůnek J, Gong X \& Peng Z. 2015. Modeling soil water dynamics in a drip-irrigated intercropping field under plastic mulch. Irrigation Science 33(4):289-302

Pereira LS, Oweis T \& Zairi A. 2002. Irrigation management under water scarcity. Agricultural water management 57(3):175-206

Sanders DC, Howell TA, Hile MMS, Hodges L, Meek D \& Phene CJ. 1989. Yield and quality of processing tomatoes in response to irrigation rate and schedule. Journal of the American Society for Horticultural Science 114(6): 904-908

Singandhupe RB, Rao GG SN, Patil NG \& Brahmanand PS. 2003. Fertigation studies and irrigation scheduling in drip irrigation system in tomato crop (Lycopersiconesculentum L.). European Journal of Agronomy 19(2):327-340

Tan CS. 1995. Effect of drip and sprinkle irrigation on yield and quality of five tomato cultivars in Soutwestern Ontario. Canadian Journal of Plant Science 75(1):225230

Thompson TL and Doerge TA. 1996a. Nitrogen and water interactions in subsurface trickle-irrigated leaf lettuce I: Plant response. Science Society of America Journal 60(1):163-168

Thompson TL and Doerge TA. 1996b. Nitrogen and water interactions in subsurface Trickle- irrigated leaf lettuce. II: Agronomic, economic, and environmental Outcomes. Science Society of America Journal 60(1):168-173

Tiwari KN, Mal PK, Singh RM \& Chattopadhyay A. 1998. Feasibility of Drip Irrigation Under Different Soil Covers in Tomato. Journal of Agricultural Engineering 35(2):41-49

Yohannes $\mathrm{F}$ and Tadesse T. 1998. Effect of drip and furrow irrigation and plant spacing on yield of tomato at Dire Dawa, Ethiopia. Agricultural Water Water Management 35(3):201-207 